\title{
İntravitreal Enjeksiyon Sonrası Ortaya Çıkan Rhizobium radiobacter Salgınının Mikrobiyolojik Analizi
}

\section{The Microbiological Analysis of a Rhizobium radiobacter Outbreak After Intravitreal Injection}

\author{
Mehmet PARLAK"

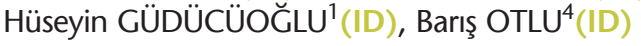 \\ ${ }^{1}$ Van Yüzüncü Yıl Üniversitesi Tıp Fakültesi, Tıbbi Mikrobiyoloji Anabilim Dalı, Van. \\ ${ }^{1}$ Van Yuzuncu Yil University Faculty of Medicine, Department of Medical Microbiology, Van, Turkey. \\ ${ }^{2}$ Van Yüzüncü Yıl Üniversitesi Tıp Fakültesi, Göz Hastalıkları Anabilim Dalı, Van. \\ ${ }^{2}$ Van Yuzuncu Yil University Faculty of Medicine, Department of Ophthalmology, Van, Turkey. \\ ${ }^{3}$ Yüksekova Devlet Hastanesi, Mikrobiyoloji Laboratuvarı, Hakkari. \\ 3 Yuksekova State Hospital, Microbiology Laboratory, Hakkari, Turkey. \\ 4 İnönü Üniversitesi Tıp Fakültesi, Tıbbi Mikrobiyoloji Anabilim Dalı, Malatya. \\ ${ }^{4}$ Inonu University Faculty of Medicine, Department of Medical Microbiology, Malatya, Turkey.
}

Makale Atıfı: Parlak M, Batur M, Ölmez S, Güdücüoğlu H, Otlu B. Intravitreal enjeksiyon sonrası ortaya çıkan Rhizobium radiobacter salgınının mikrobiyolojik analizi. Mikrobiyol Bul 2020;54(2):235-245.

\section{ÖZ}

Doğada bulunan ve tümörijenik bitki hastalıklarına neden olan Rhizobium radiobacter, özellikle altta yatan hastalığı olan kişilerde fırsatçı enfeksiyonlara neden olabilmektedir. Çalışmamızda Göz Hastalıkları Kliniğinde intravitreal ranibizumab enjeksiyonu sonrasında R.radiobacter bakterisinin etken olduğu 10 hastada ortaya çıkan endoftalmit olguları mikrobiyolojik açıdan irdelenmiştir. Van Yüzüncü Yıl Üniversitesi Tıp Fakültesi Göz Hastalıkları Kliniğinden Mikrobiyoloji Laboratuvarına 21.12.2016 tarihinde intravitreal ranibizumab enjeksiyonu yapılmış olan 13 hastaya ait vitreus sıvısı örnekleri mikrobiyolojik açıdan incelenmesi amacıyla gönderilmiştir. Örnekler Gram boyama ile boyanıp mikroskop altında incelenmiş ve \%5 koyun kanlı agar ile "Eosin Methylene Blue (EMB)" agara ekimi yapılmışıı. Besiyerleri \%5 $\mathrm{CO}_{2}{ }^{\prime l i}$ ortamda, $37^{\circ} \mathrm{C}^{\prime}$ de $18-24$ saat inkübasyona bırakılmış ve üreyen kolonilere katalaz, oksidaz ve üreaz testleri yapılmıştır. Vitreus sıvısı örneklerinde üreyen bakteriler BD Phoenix (Becton Dickinson, ABD), Vitek 2 Compact (BioMerieux, Fransa) ve Vitek MS (BioMerieux, Fransa) sistemleri ile tanımlanmış ve antibiyotik duyarlıık testleri yapılmıştır. Ayrıca izolatlara 16S rDNA dizi analizi yapılmış ve izolatlar arasındaki klonal ilişkinin tespiti için "pulsed field gel electrophoresis (PFGE)" yöntemi uygulanmıştır. Kültürlerde üreme saptandıktan sonra (işlemden bir gün sonra) işlemin yapıldığı alanda bulunan eşyalardan, tıbbi alet ve gereçlerden, sağlık çalışanlarının ellerinden ve yeni enjeksiyon çözeltisinden kültür örnekleri alınmıştır. On üç hastaya ait vitreus sıvısı örneklerinin 10'unun kültüründe R.radiobacter üremesi olurken 3'ünde bakteri üremesi saptanmamıştır. Mikroskobik incelemede mikroorganizmanın gram-negatif basil olduğu görülmüş ve izolatların R.radiobacter ile uyumlu olarak, nonfermenter, hareketli, katalaz/oksidaz/üreaz pozitif olduğu saptanmıştır. İzolatların tamamı, BD Phoenix (Becton Dickinson, ABD), Vitek 2 Compact 
(BioMerieux, Fransa) ve Vitek MS (BioMerieux, Fransa) (database v2.0) otomatize sistemlerinin 3'ü ile de R.radiobacter olarak tanımlanmışır. R.radiobacter izolatları; ampisilin, amoksisilin-klavulonik asit, trimetoprim-sülfametoksazol, sefotaksim ve seftazidime dirençli; sefuroksim, sefepim, amikasin, gentamisin, imipenem, meropenem, siprofloksasin, levofloksasin, piperasilin-tazobaktama duyarlı bulunmuştur. 16S rDNA dizi analizi ile izolatlar R.radiobacter olarak tanımlanmıştır. PFGE sonucunda izolatların tamamının aynı bant profiline sahip olduğu görülmüştür. Aynı bant profiline sahip R.radiobacter izolatları muhtemel olarak aynı kaynaktan bulaş olduğunu ortaya koymaktadır. Ancak işlemin yapıldığı alanda bulunan eşyalardan, tıbbi alet ve gereçlerden, sağlık personelinin ellerinden ve yeni enjeksiyon çözeltisinden yapılan kültürlerde R.radiobacter üremesi saptanamamış ve etkenin kaynağı belirlenememiştir. Elde edilen sonuçlar, intravitreal enjeksiyon işleminin R.radiobacter enfeksiyonu açısından risk taşıdığını göstermektedir. Buna göre, işlemden önce ve işlem esnasında dezenfeksiyon ve antisepsi şartlarının sağlanması bu gibi enfeksiyonların önlenmesi açısından önem taşımaktadır. Bu çalışma, R.radiobacter endoftalmitinde aynı suşun neden olduğu ilk epidemik salgın ve intravitreal enjeksiyon sonrası R.radiobacter' in etken olarak bildirildiği ikinci makaledir.

Anahtar kelimeler: Rhizobium radiobacter; endoftalmit; intravitreal enjeksiyon.

\section{ABSTRACT}

Rhizobium radiobacter, which is found in nature and causes tumorigenic plant diseases can lead to opportunistic infections, especially in people with underlying diseases. In our study, endophthalmitis that observed in ten patients caused by R.radiobacter bacteria after intravitreal ranibizumab injection in Ophthalmology Clinic were examined microbiologically. Vitreous fluid samples of 13 patients who received intravitreal ranibizumab injection were sent to the Microbiology Laboratory from Van Yuzuncu Yil University Faculty of Medicine's Ophthalmology Clinic for microbiological examination in December 21, 2016. Samples were examined under microscope after staining with Gram and cultured with $5 \%$ sheep blood agar and Eosin Methylene Blue (EMB) agar. The culture plates were incubated for 18-24 hours at $37^{\circ} \mathrm{C}$ in $5 \% \mathrm{CO}_{2}$. At the end of this period, catalase, oxidase, and urease tests were performed on the colonies. The identification and antibiotic susceptibility tests of microorganisms growing in vitreous fluid samples were performed using BD Phoenix (Becton Dickinson, USA), Vitek 2 Compact (BioMerieux, France), and Vitek MS (BioMerieux, France) systems. In addition, 16S rDNA sequence analysis was performed and the pulsed field gel electrophoresis (PFGE) method was used to determine the clonal relationship between the isolates. After growing in cultures (one day after the procedure), culture samples were collected from the objects, medical tools and equipment, hands of healthcare staff and a new injection solution in the area where the procedure was performed. R.radiobacter was isolated in 10 of the vitreous fluid samples of 13 patients, and no bacterial growth was detected in 3. The microorganisms were found to be gram-negative bacilli, non-fermenter, motile, catalase/oxidase/urease positive, in compliance with R.radiobacter. All isolates were identified as R.radiobacter by BD Phoenix (Becton Dickinson, USA), Vitek 2 Compact (BioMerieux, France), and Vitek MS (BioMerieux, France) (database v2.0) systems. R.radiobacter isolates were found to be resistant to ampicillin, amoxicillin/clavulanate, trimethoprim/ sulfamethoxazole, cefotaxime and ceftazidime; susceptible to cefuroxime, cefepime, amikacin, gentamicin, imipenem, meropenem, ciprofloxacin, levofloxacin and piperacillin/tazobactam. The isolates were identified as R.radiobacter by $16 \mathrm{~S}$ rDNA sequence analysis. PFGE showed that all isolates had the same band profile. R.radiobacter isolates with the same band profile likely revealed that the contamination was from the same source. However, the growth of R.radiobacter was not detected in the cultures made from the objects, medical instruments and supplies, the hands of healthcare professionals and the new injection solution in the area where the procedure was performed, and the source of the agent could not be determined. The results have shown that intravitreal injection procedure carries a risk for $R$.radiobacter infection. Disinfection and antisepsis conditions, before and during the procedure, is important for the prevention of such infections. This study is the first epidemic outbreak report of endophthalmitis caused by the same strain of R.radiobacter and the second article in which R.radiobacter was reported as the cause of endophthalmitis after intravitreal injection.

Keywords: Rhizobium radiobacter; endophthalmitis; intravitreal injection. 


\section{Gíriş}

Rhizobium radiobacter, önceleri Agrobacterium cinsi içerisinde sınıflandııımış ve $\mathrm{Ag}$ robacterium tumefaciens (sin. Agrobacterium radiobacter) olarak adlandırılmıştır. 16S rDNA dizi analizi sonucunda R.radiobacter adını almıştır ${ }^{1}$. Rhizobium türleri arasında (örn. R.rhizogenes, R.vitis, R.rubi, R.radiobacter, R.undicola) R.radiobacter insanlarda en sık hastalığa neden olan türdür. Rhizobium türü bakteriler; doğada bulunan ve sıkıkla tümörijenik bitki hastalığına neden olan gram-negatif basiller olup oksidaz, katalaz ve üreaz pozitif, hareketli, nonfermenter, aerobik ve sporsuz özelliktedir ${ }^{2,3}$. R.radiobacter ise bitki patojeni olmasının yanı sıra insanlarda fırsatçı enfeksiyonlara neden olabilmektedir ${ }^{4}$. Önceki yıllarda Rhizobium türlerinin klinik örneklerden izolasyonu sıklıkla kontaminasyon veya kolonizasyon olarak değerlendirilmiştir ${ }^{5}$. Ilk olarak 1980 yılında prostetik aort kapağında endokardit etkeni olarak izole edilerek enfeksiyon etkeni olarak kabul edilmiştir ${ }^{6}$. Bakteremi, selülit, peritonit, endokardit ve üriner sistem enfeksiyonlarında etken olarak bildirilmiştii ${ }^{7,8}$. Katarakt cerrahisi sonrası endoftalmit etkeni olarak raporlandığı az sayıda literatür de mevcuttur ${ }^{4,9-11}$. Bu enfeksiyonlar sıklıkla kronik hastalıkları olan veya bağışıkık sistemini baskılayıcı kanser, kazanılmış immün yetmezlik sendromu (AIDS), hematolojik malignansi gibi durumu olan kişilerde görülüyor olsa da nadiren predispozan faktörü olmayan kişilerde de bildirilmiştir. Aynı zamanda santral venöz kateter, nefrostomi tüpü ve peritoneal kateter gibi bakterinin adezyon olanağını kolaylaştıran medikal cihazlar bulunan kişilerde enfeksiyonlar daha sık bildirilmiştir ${ }^{8,12}$.

Çalışmada intravitreal ranibizumab enjeksiyonu sonrasında R.radiobacter bakterisinin etken olduğu 10 hastada ortaya çıkan endoftalmit olguları mikrobiyolojik açıdan irdelenmiştir. Bakterinin tanımlanması ve antibiyotik duyarılık çalışmaları farklı yöntemlerle yapılmış, aynı zamanda izolatlar 16S rDNA dizi analizi ile tanımlanarak "pulsed field gel electrophoresis (PFGE)" ile izolatlar arası klonal ilişki araştırılmıştır.

\section{GEREÇ ve YÖNTEM}

Bu çalısma, Van Yüzüncü Yıl Üniversitesi Tıp Fakültesi Girişimsel Olmayan Klinik Araştırmalar Etik Kurulunun onayı ile gerçekleştirildi (Tarih: 21.11.2017 ve Karar no: 21.11.2017/08).

\section{Olguların Özellikleri}

Van Yüzüncü Yıl Üniversitesi Tıp Fakültesi Göz Hastalıkları Kliniğinde 21.12.2016 tarihinde 22 hastaya intravitreal ranibizumab enjeksiyonu yapıldı. işlem sonrası farklı günlerde gözünde ağrı, kızarıklık, görmede azalma ortaya çıkan 13 hastadan endoftalmit ön tanısıyla vitreus örnekleri alınarak mikrobiyoloji laboratuvarına gönderildi. İntravitreal ranibizumab enjeksiyonundan bir gün sonra 5 hastadan, 2 gün sonra ise 6 hastadan vitreus sIVISı örnekleri mikrobiyolojik açıdan incelenmesi amacıyla gönderildi. Bir hastada 53 gün sonra, bir hastada da 110 gün sonra endoftalmit bulguları olması üzerine bu hastalardan da alınan vitreus sıvısı örnekleri incelendi. işlem uygulanan 9 hastada herhangi bir klinik bulgu ortaya çıkmadı. 


\section{Kültür Örneklerinin İncelenmesi}

Endoftalmit gelişen 13 hastadan alınan vitreus sıvısı örnekleri mikrobiyoloji laboratuvarına incelenmesi amacıyla gönderildi. Örnekler Gram boyama ile boyanarak mikroskop altında incelendi, ayrıca \%5 koyun kanlı agar ve "Eosin Methylene Blue (EMB)" agara ekimi yapıldı. Besiyerleri \%5 $\mathrm{CO}_{2}^{\prime}$ li ortamda, $37^{\circ} \mathrm{C}^{\prime}$ de $18-24$ saat inkübasyona bırakıldı. Bu süre sonunda üreyen koloniler, konvansiyonel yöntemler (katalaz testi, oksidaz testi, üreaz testi), BD Phoenix (Becton Dickinson, ABD), Vitek 2 Compact (BioMerieux, Fransa) otomatize sistemleri ve İnönü Üniversitesi Tıp Fakültesi Tıbbi Mikrobiyoloji Laboratuvarında matriks aracılı lazer desorbsiyon iyonizasyon-uçuş zamanlı kütle spektrometresi (MALDI-TOF MS) temelli bir sistem olan Vitek MS (BioMerieux, Fransa) (database v2.0) ile tanımlandı. Üreyen bakterilerin antibiyotik duyarlılık testleri de BD Phoenix ve Vitek 2 Compact otomatize sistemleri ile yapıldı.

\section{Çevre Kültürleri}

Kültürde üreme saptandıktan hemen sonra intravitreal enjeksiyonların yapıldığı odadaki hasta masası, duvar, klima, dolap ve lavabodan örnekler alındı. Bunlara ek olarak iki besiyeri plağı 30 dakika boyunca odada açık bırakılmak suretiyle ortam kültürü alındı. Hastalara intravitreal enjeksiyon yapılırken kullanılan malzemelerin bir kısmı aynı gün tıbbi atığa atılmış olduğundan, işlem sırasında kullanılan materyallerden sadece batikon, batikon şişesi ağzı ve Alcaine damladan örnek alındı. Enjeksiyonun yapıldığı gün kullanılmayan ancak normalde bu işlem için gerekli olan ringer laktat çözeltisi, steril cerrahi eldivenler, enjektör uçları, steril spanç, kapak spekülümler, işaretleme pergeli, batikonun döküldüğü kap ve intravitreal olarak enjekte edilen ranibizumab flakonu içi ile yüzeyinden örnekler alınarak kültürleri yapıldı. Ayrıca intravitreal enjeksiyon işlemini gerçekleştiren doktor ve sağlık personelinin el ve burun kültürleri de çalışıldı.

\section{$16 S$ rDNA Dizi Analizi}

İnönü Üniversitesi Tıp Fakültesi Tıbbi Mikrobiyoloji Laboratuvarında izolatların; özgül p8FPL 5'-AGT TTG ATC ATG GCT CAG-3' ve p806R 5'-GGA CTA CCA GGG TAT CTA AT3' primerleri kullanılarak kısmi 16S rDNA dizi analizi yapıldı. Bu amaçla ilk olarak kolon temelli DNA izolasyon kiti (DNA mini kit, Qiagen, Almanya) ile izolatların DNA ekstraksiyonu yapıldı. İzolasyonun ardından yaklaşık 800 baz çiftlik 16S rDNA bölgesi her iki yönde; GeneAmp PCR System 9700 (AppliedBiosystems/ABD) Isı döngü cihazı kullanılarak çoğaltıldı. Amplifikasyon koşulları; $94^{\circ} \mathrm{C}^{\prime}$ de 3 dakikalık ilk denatürasyonu takiben, 35 döngü olarak $94^{\circ} \mathrm{C}^{\prime}$ de 30 saniye denatürasyon, $60^{\circ} \mathrm{C}^{\prime}$ da 30 saniye primer bağlanması ve $72^{\circ} \mathrm{C}^{\prime}$ de 1 dakika uzama olarak uygulandı. \%1'lik agaroz jel elektroforezinde elde edilen bantlar dizi analizinde kullanılmak üzere QIAquick gel ekstraksiyon kiti (Hilden, Almanya) kullanılarak saflaştırıldı. ABI Prism Big Dye Terminator v3.1 (Applied Biosystems, ABD) kiti kullanılarak, her iki yönde $96^{\circ} \mathrm{C}^{\prime}$ de 10 saniye, $50^{\circ} \mathrm{C}^{\prime}$ de 5 saniye ve $60^{\circ} \mathrm{C}^{\prime}$ de 6 dakika olmak üzere toplam 35 döngü dideoksinükleotit dizi analizi işlemi gerçekleştirildi (Gene Amp PCR System 9700, Applied Biosystems, ABD). Dizi analizi ürünleri, ABI Prism 310 
Genetic Analyser (Applied Biosystems, ABD) cihazına yüklendi ve elde edilen kromatogramlar, "National Center for Biotechnology Information (NCBI)" da yer alan Gen Bankası ve BLAST (Basic Local Alignment Search Tool) sunucusu kullanılarak veri bankasında kayıtlı diğer izolatlar ile karşılaştırıldı. Elde edilen dizilerin tür düzeyinde tanımlamalarında yüksek oranda doğruluğundan emin olmak için; E-değeri 0.0 ve maksimum benzerlik oranları \%99'un üzerinde olan veriler tanımlamada kullanıldı. Toplamda yaklaşık 1200 nükleotit analizi yapıldı ve izolat tanımlandı.

\section{Klonal ilişkinin Tespiti}

İzolatlar arasındaki klonal ilişkinin tespiti için; PFGE yöntemi uygulandı. Kromozomal DNA Spe-I enzimi ile kesilerek elektroforez yöntemi Butler ve arkadaşlarının ${ }^{13}$ uyguladıkları koşulların küçük modifikasyonları ile uygulandı. Buna göre; CHEF-DR II sisteminde (Bio-Rad, Nazareth, Belçika); başlangıç vuruş süresi 2.9 saniye, bitiş vuruş süresi 35.4 saniye olmak üzere toplam 20 saatlik elektroforez uygulandı. Agaroz jel elektroforezi ile elde edilen bant profiller UV transilüminatör altında fotoğraflandı.

Her iki genotipleme yöntemi ile elde edilen bant profillerinin analizi Gel Compar II (version 3.0; Applied Maths, Sint-Martens-Latem, Belçika) yazılım sistemi ile değerlendirildi. Bu program ile aynı jel içerisinde veya jeller arasında karşılaştırma yaparken, normalizasyon, pozisyon tolerans ve optimizasyon değerleri ayarlanmaktadır. Bu amaçla aynı jel üzerinde tercihen üç farklı "referans bakteri/DNA profili" jelin başında, ortasında ve sonunda kullanılmaktadır. Moleküler belirteç olarak kullanılan bu referans bant profillerinde önemli olan DNA parçacıklarının jel içindeki göçleridir. Bu amaçla "PFGE pulse" belirteçler kullanılabildiği gibi bakteri izolatları da kullanılabilmektedir. Çalışmamızda, klinik R.radiobacter izolatlarından biri bu amaçla kullanıldı ve "bantların jel içinde normalizasyonu" bu izolatın bant profilleri kullanılarak yapıldı.

Bant analizleri için benzerlik hesaplarının yapılmasında Dice Benzerlik Katsayısı (Dice Smilarity Coefficient) ve kümeleşme analizi için de "Unweighthed Pairvise Grouping Matematical Avenaging (UPGMA)" yöntemi kullanıldı. İzolatlar benzerlik katsayıları göz önüne alınarak, birbirleriyle \%95'in üzerinde benzerlik gösteren izolatlar aynı klona ait kabul edildi.

\section{BULGULAR}

21.12.2016 tarihinde intravitreal ranibizumab enjeksiyonu yapılmış ve 1 gün sonra örnek gönderilen 5 hastada, 2 gün sonra örnek gönderilen 6 hastanın 4 'ünde ve 110 gün sonra örnek gönderilen 1 hastada olmak üzere toplam 10 hastada üreme saptanmıştır. Enjeksiyondan 53 gün sonra endoftalmit gelişen hastada üreme saptanmamıştır. Olgulara ait klinik ve mikrobiyolojik bulgular Tablo I'de özetlenmiştir.

Klinik örneklerden hazırlanan Gram boyalı preparatlarda x100'lük büyütmede her alanda 4-5 polimorfonükleer lökosit ve gram-negatif basiller görülmüştür. On sekiz-24 saatlik inkübasyon sonrası kanlı agarda mukoid, gri koloniler; EMB agarda zayıf üremiş, küçük koloniler saptanmıştır. EMB agardaki koloniler 48 saatlik inkübasyon sonrası yuvar- 


\begin{tabular}{|c|c|c|c|c|c|c|c|}
\hline Olgu & Yaş & Cinsiyet & $\begin{array}{l}\text { Altta yatan } \\
\text { hastalık } \\
\text { durumu }\end{array}$ & $\begin{array}{c}\text { Örnek geliş̧ } \\
\text { tarihi }\end{array}$ & $\begin{array}{l}\text { BD Phoenix } \\
\text { Vitek } 2 \text { Comp. } \\
\text { Vitek } 2 \mathrm{MS}\end{array}$ & $\begin{array}{c}16 S \text { rDNA } \\
\text { dizi analizi }\end{array}$ & $\begin{array}{c}\text { PFGE } \\
\text { genotipi }\end{array}$ \\
\hline 1 & 53 & Erkek & DM & 22.12 .2016 & R.radiobacter & R.radiobacter & A \\
\hline 2 & 85 & Kadın & $\mathrm{HT}, \mathrm{YBMD}$ & 22.12 .2016 & R.radiobacter & R.radiobacter & A \\
\hline 3 & 47 & Erkek & DM & 22.12 .2016 & R.radiobacter & R.radiobacter & A \\
\hline 4 & 52 & Kadın & DM & 22.12 .2016 & R.radiobacter & R.radiobacter & A \\
\hline 5 & 64 & Erkek & DM, HT, YBMD & 22.12 .2016 & R.radiobacter & R.radiobacter & A \\
\hline 6 & 56 & Erkek & DM & 23.12 .2016 & R.radiobacter & R.radiobacter & A \\
\hline 7 & 65 & Kadın & $\mathrm{HT}, \mathrm{YBMD}$ & 23.12 .2016 & R.radiobacter & R.radiobacter & A \\
\hline 8 & 69 & Erkek & $\mathrm{DM}, \mathrm{HT}$ & 23.12 .2016 & R.radiobacter & R.radiobacter & A \\
\hline 9 & 89 & Kadın & $\mathrm{DM}, \mathrm{HT}$ & 23.12 .2016 & Üreme yok & - & - \\
\hline 10 & 81 & Kadın & YBMD & 23.12 .2016 & R.radiobacter & R.radiobacter & A \\
\hline 11 & 77 & Erkek & YBMD & 23.12 .2016 & Üreme yok & - & - \\
\hline 12 & 64 & Erkek & DM & 12.02 .2017 & Üreme yok & - & - \\
\hline 13 & 84 & Erkek & YBMD & 10.04 .2017 & R.radiobacter & R.radiobacter & $A$ \\
\hline
\end{tabular}

lak, şeffaf renkli olarak izlenmiştir. Besiyerindeki kolonilerin Gram boyalı incelemesinde gram-negatif basil olduğu görülmüş ve izolatların R.radiobacter ile uyumlu olarak, nonfermenter, hareketli, katalaz/oksidaz/üreaz pozitif olduğu saptanmıştır. Vitreus sıvısı örneklerinde R.radiobacter üremesi saptanan 9 hastadan, 2 gün sonra gelen kontrol vitreus SIVISı örneklerinde bakteri üremesi olmamıştır.

İzolatların tamamı, BD Phoenix (Becton Dickinson, ABD), Vitek 2 Compact (BioMerieux, Fransa) ve Vitek MS (BioMerieux, Fransa) (database v2.0) yöntemlerinin üçü ile de R.radiobacter olarak tanımlanmıştır. R.radiobacter izolatlarının ampisilin, amoksisilin-klavulonik asit, trimetoprim-sülfametoksazol, sefotaksim ve seftazidime dirençli; sefuroksim, sefepim, amikasin, gentamisin, imipenem, meropenem, siprofloksasin, levofloksasin, piperasilin-tazobaktama duyarlı oldukları tespit edilmiştir.

Intravitreal enjeksiyonların yapıldığı odadaki malzemeler, ortam kültüründen alınan plaklar, işlem sırasında kullanılan batikon, batikon şişesi ağzı ve Alcaine damladan, enjeksiyonun yapıldığı gün kullanılmayan ancak normalde bu işlem için gerekli olan tıbbi sarf malzemeler (ranibizumab flakonu içi ile yüzeyi dahil) ve enjeksiyon işlemini gerçekleştiren doktor ve sağlık personelinin el ve burun kültürlerinin hiçbirisinde R.radiobacter üremesine rastlanmamıştır. Etkenin kaynağı tespit edilememiştir.

16S rDNA dizi analizi ile toplamda yaklaşık 1200 nükleotidin analizi yapılmış ve izolat \%99 oranda R.radiobacter (Agrobacterium tumefaciens) (GenBank accession No. AB749221.1) olarak tanımlanmıştır. 


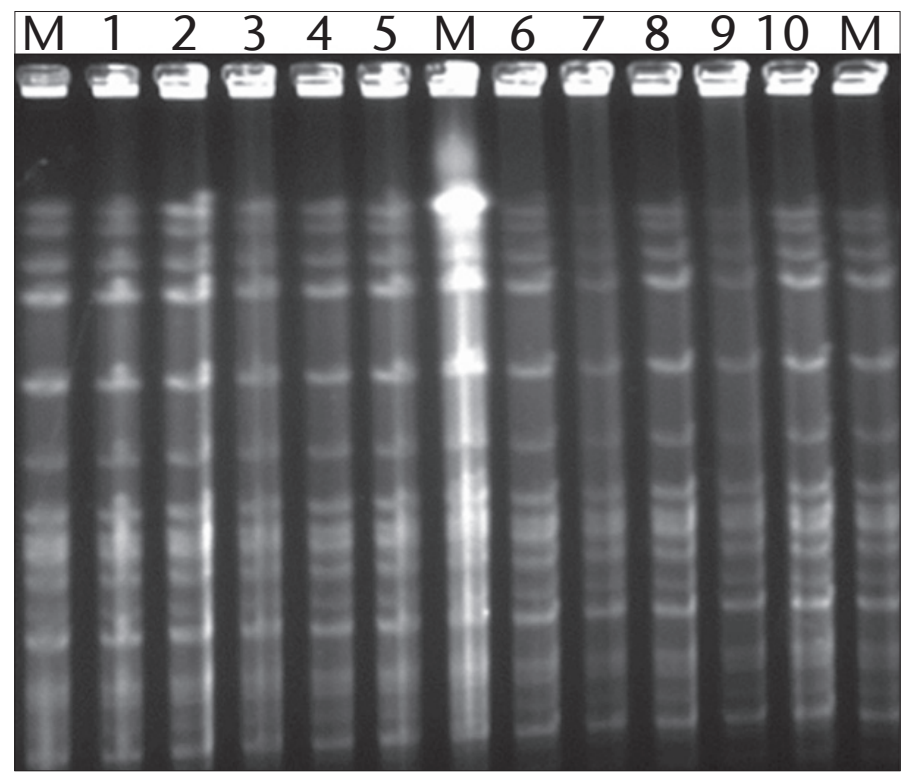

Resim 1. Rhizobium radiobacter izolatlarının PFGE görüntüsü (M: Moleküler ağırlık belirteci).

İzolatlar arasındaki klonal ilişkinin tespiti için PFGE yöntemi uygulanmıştır. Çalışmamızda "bantların jel içinde normalizasyonu" klinik R.radiobacter izolatlarından biri "PFGE pulse" belirteci olarak jelin başında, ortasında ve sonunda kullanılarak yapıldı. Benzerlik katsayıları göz önüne alınarak, birbirleriyle \%95'in üzerinde benzerlik gösteren izolatlar aynı klonda kabul edilmiş ve izolatların tamamının aynı bant profiline sahip olduğu görülmüştür (Resim 1).

\section{TARTIŞMA}

R.radiobacter, doğada bulunan ve insanlarda fırsatçı enfeksiyonlara neden olabilen nonfermentatif gram-negatif basildir ${ }^{2,5}$. Enfeksiyonlar sıklıkla kateterize ve bağışıklık sistemi baskılanmış kişilerde raporlanmıştır ${ }^{14}$. R.radiobacter, en sık bakteremi etkeni olarak insan immün yetmezlik virüsü (HIV) ile enfekte hastalar, onkolojik ve geriatrik hastalardan izole edilmiştir. Bu grup hastalar içinde ise daha çok kalıcı kateteri olan hastalarda enfeksiyonlar görülmüştür ${ }^{15}$. Kalıcı kateteri olan hastalardaki enfeksiyon sıklığı, bakterinin silikon yüzeylere ekstraselüler slime ile yapışabilme yeteneğine bağlanmıştır ${ }^{16}$. Ayrıca selülit, miyozit $^{7}$, peritonit ${ }^{17}$, endokardit ${ }^{18,19}$, septik pulmoner emboli ${ }^{20}$, septik şok ${ }^{21}$ ve üriner sistem enfeksiyonlarında ${ }^{22}$ da etken olarak bildirilmiştir. Kontakt lens ilişkili keratit ${ }^{23}$ ve katarakt cerrahisi sonrası endoftalmit etkeni olarak bildirilen az sayıda olgu bulunmaktadır $r^{4,9-11}$.

R.radiobacter'in etken olarak saptandığı ilk endoftalmit olgusu Miller ve arkadaşları ${ }^{9}$ tarafından 1996 yılında bildirilmiştir. Katarakt cerrahisi geçirmiş 70 yaşında erkek hasta, cerrahi sonrası evinde bahçe işleriyle ilgilendiği bilgisini vermiştir. Dört gün sonra gözde 
terleme, pürülan akıntı ve ağrı şikayetleri gelişmiştir. Vitreus sıvısı örneğinde R.radiobacter üremiştir. R.radiobacter'in etken olduğu bir diğer endoftalmit olgusu ise 2003 yılında Namdari ve arkadaşları ${ }^{4}$ tarafından bildirilmiştir. Altmış iki yaşında katarakt ekstraksiyonu yapılan hastada endoftalmit gelişmiş ve vitreus SIVISı örneğinden R.radiobacter izole edilmiştir. Hasta amikasin ve vankomisin tedavisi ile düzelmiş ancak iki ay sonra şikayetleri tekrarlamıştır. Hastanın vitreus sıvısı örneğinde aynı bakteri üremesi üzerine hastanın intraoküler göz içi lens implantı çıkarılmış, gentamisin ve siprofloksasin ile kür sağlan-

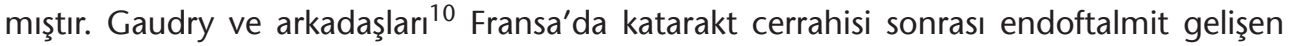
farklı hastanelerdeki üç hastanın vitreus sıvısı ile aköz hümör örneklerinde etken olarak R.radiobacter patojenini saptamışlardır. Ayrıca miyopiyi düzeltmek için lens implantasyonu yapılan bir hastada da R.radiobacter endoftalmiti görülmüştür ${ }^{24}$.

Ranibizumab yaşa bağlı maküla dejenerasyonu gelişmiş olan hastalarda ve diyabetik maküler ödem tedavisinde sıklıkla kullanılan bir anti-vasküler endotelyal büyüme faktörü (VEGF) preparatıdır. Ranibizumab enjeksiyonu sonrası R.radiobacter'in etken olarak saptandığı ilk ve tek endoftalmit olgusu Joshi ve arkadaşları ${ }^{25}$ tarafından 2012 yılında Amerika Birleşik Devletler'nde bildirilmiştir. Yaşa bağlı maküla dejenerasyonu gelişmiş 78 yaşında bir hasta ranibizumab enjeksiyonundan yedi gün sonra görmede azalma, gözde ağrı ve kızarıklık şikayetleriyle kliniğe başvurmuş ve vitreus sıvısı kültüründe R.radiobacter üremesi olmuştur. İzolatın antibiyotik duyarlıık profili çalışma izolatlarımızla benzer şekilde seftazidime dirençli, siprofloksasin ve amikasine duyarlı olarak bildirilmiştir. Bu olgu yaş ve hastanın altta yatan diabetes mellitus ve hipertansiyon gibi kronik hastalıkları olması yönüyle de çalışmamızla benzer şekildedir.

Göz hastalıkları kliniğinde 21.12.2016 tarihinde 22 hastaya intravitreal ranibizumab enjeksiyonu yapılmış, bu hastalardan 11'inde görme ile ilgili şikayetler iki gün içinde gelişmiş, bir hastada iki ay sonra, bir hastada ise dört ay sonra endoftalmit gelişmiştir. íki hastada enjeksiyondan birkaç ay sonra enfeksiyon gelişmesi kişilerin bağışıklık durumlarının daha iyi olması veya bulaşan bakteri yoğunluğunun daha az olması ile ilişkili olabileceğini düşündürmüştür. Ayrıca aynı gün enjeksiyon yapılmış olan ama endoftalmit gelişmeyen dokuz hastanın, bağışıklık sistemleri güçlü olduğu için, az bakteri inokülasyonuna maruz kaldıkları için veya bakteri ile kontamine edilmedikleri için endoftalmit gelişmemiştir. Yirmi iki hastanın toplam 13'ünde endoftalmit gelişmiş, bunların 10'unda R.radiobacter üremesi saptanmıştır. Endoftalmit gelişen hastaların tamamında diabetes mellitus veya yaşa bağlı maküla dejenerasyonu mevcuttu. Dhatariya ve arkadaşları, diabetes mellitus hastalığının R.radiobacter enfeksiyonları açısından risk oluşturduğunu bildirmişlerdir. Onlara göre kontrol altına alınmamış diyabet kişide bir nevi immünsüprese durum oluşturmaktadır ${ }^{26}$. Ayrıca Şen ve arkadaşlarının Türkiye'den raporladıkları ve etken olarak R.radiobacter üreyen fournier gangrenli hastanın da diabetes mellitus hastası olduğu bildirilmiştir ${ }^{27}$.

R.radiobacter toprak kaynaklı bir mikroorganizmadır. Katarakt cerrahisi sonrası endoftalmit gelişmiş olan hastalarda sıklıkla cerrahi öncesi veya sonrasında patojen bakteri ile temas olduğu düşünülmektedir. Literatürde de R.radiobacter endoftalmiti bildirilmiş olan 
hastalarda bahçe işleriyle ilgilenme veya golf oynama gibi toprak teması bildirilmiştir ${ }^{4,9,12}$. Ayrıca R.radiobacter hastane kaynaklı enfeksiyonlardan da sorumludur. Pereira ve arkadaşları ${ }^{9}$ farklı hastalardan alınmış olan 11 klinik örnekte R.radiobacter üremesi saptamışlardır. Örnekler aseptik şekilde alınıp, steril kaplarda serum fizyolojik çözeltisi ile seyreltilip besiyerlerine ekilmiş ve R.radiobacter üremesi olmuştur. Psödoepidemiden şüphelenip çevre örnekleri alınınca, serum fizyolojik şişesinden alınan örneklerde aynı bakterinin ürediği görülmüş ve R.radiobacter'e bağlı ilk psödoepidemi bildirilmiştir ${ }^{28}$. Lai ve arkadaşları ${ }^{29}$ tarafından 1996-2002 yılları arasında aynı hastanede, klinik örneklerinden R.radiobacter izole edilmiş olan 13 hastaya ait izolatlara PFGE yapılmıştır. Ancak izolatlar arası klonal benzerlik saptanamamış ve nozokomiyal yayılım gösterilememiştir. Olgularımızda ise 10 farklı hastadan izole edilmiş olan R.radiobacter izolatlarının tamamının PFGE ile aynı bant profiline sahip olduğu görülmüştür. Bu çalışma ile literatürde ilk kez epidemik seyir gösteren R.radiobacter endoftalmiti bildirilmiştir.

R.radiobacter pek çok antibiyotiğe dirençli bir bakteridir. Bu direncin nedeni bakterinin toprakta, antibiyotik üreten pek çok mikroorganizmayla bir arada bulunması olarak açıklanmıştır ${ }^{30}$. Siprofloksasin, trimetoprim-sülfametoksazol, seftriakson, imipenem, gentamisin ve amikasin bu bakteri için tedavi amaçlı kullanılabilecek antibiyotiklerden bazılarıdır. İzolatlar arası antibiyotik duyarlılık paterni değişiklik gösterebileceğinden klinik örnekten izole edilen her bakteri için antibiyotik duyarlılık çalışmalarının yapılması gereklidir ${ }^{5}$. Çalışmamızdaki hastalara kültür sonuçları çıkana kadar ampirik olarak, endoftalmit olgularında standart tedavi olan vankomisin ve seftazidim başlanmıştır. Vankomisin gram-negatif bakterilere karşı etkisizdir ayrıca duyarlılık çalışması sonucunda seftazidime de direnç saptanması üzerine tedavi imipenem silastatin sodyum ile değiştirilmiştir. R.radiobacter izole edilen hastaların dokuzuna vitrektomi ameliyatı yapılmıştır. Hastalar tedaviden fayda görmüş, sonrasında enfeksiyon bulgularına tekrar rastlanmamıştır.

R.radiobacter, doğada bulunan bir bakteri olsa da kişinin bağışıklık durumuna ve vücutta kateter, protez, şant gibi yabancı cisim varlığında ciddi klinik tablolara neden olabilmektedir. Hastalarımız geriatrik yaş grubu hastalar olup bir kısmında diabetes mellitus gibi predispozan faktör bulunmaktaydı. PFGE işlemi ile enfeksiyonun aynı klonda ve aynı bant profiline sahip R.radiobacter izolatları tarafından meydana geldiği tespit edilmiştir. İşlemin göz hastalıkları servisi içerisinde oluşturulmuş, yarı steril ve steril alan şeklinde birbirinden ayrı bölümler içeren ve ameliyathane şartlarının sağlandığı ortamda uygulandığı görülmüştür. İşlemin yapıldığı alanda bulunan eşyalardan, tıbbi alet ve gereçlerden, sağlık personelinin ellerinden ve yeni enjeksiyon çözeltisinden yapılan kültürlerde R.radiobacter üremesi saptanamamış ve etkenin kaynağı belirlenememiştir. Çalışmamızın kısıtlayıcı faktörü, etkenin kaynağını saptamaya yönelik yapılan kültür aşamalarının enjeksiyon işleminden bir gün sonra yapılmış olmasıdır. Ayrıca işlemde kullanılan enjeksiyon solüsyonunun bir hastaya tamamı kullanılması nedeniyle kültür örneği yeni şişe alınarak yapılmıştır. Elde edilen sonuçlar, intravitreal enjeksiyon işleminin R.radiobacter enfeksiyonu açısından risk taşıdığını göstermektedir. Buna göre, işlemden önce ve işlem esnasında dezenfeksiyon ve antisepsi şartlarının sağlanması bu gibi enfeksiyonların önlenmesi açı- 
sından önem taşımaktadır. Çalışmamız R.radiobacter endoftalmitinde aynı suşun neden olduğu ilk epidemik salgın ve intravitreal enjeksiyon sonrası R.radiobacter' in etken olarak bildirildiği ikinci makaledir.

\section{TEŞEKKÜR}

16S rDNA Dizi Analizi ve klonal ilişkinin tespiti (PFGE), İnönü Üniversitesi Tıp Fakültesi Tıbbi Mikrobiyoloji Anabilim Dalı Moleküler Mikrobiyoloji Laboratuvarında yürütülmüş olup katkılarından dolayı Dr. Öğr. Üyesi Nafia Canan GÜRSOY'a teşekkür ederiz.

\section{ÇIKAR ÇATIŞMASI}

Yazarlar bu makale ile ilgili herhangi bir çıkar çatışması bildirmemişlerdir.

\section{KAYNAKLAR}

1. Young JM, Kuykendall LD, Martinez-Romero E, Kerr A, Sawada H. Classification and nomenclature of Agrobacterium and Rhizobium. Int J Syst Evol Microbiol 2003; 53(5): 1689-95.

2. Kersters K, de Ley J. Genus III. Agrobacterium Conn 1942, 359AL, pp: 244-54. In: Krieg NR, Holt JG, eds. Bergey's Manual of Systematic Bacteriology. 1984, vol 1. Baltimore, Williams and Wilkins.

3. Young JM, Kuykendall LD, Martinez-Romero E, Kerr A, Sawada H. A revision of Rhizobium Frank 1889, with an emended description of the genus, and the inclusion of all species of Agrobacterium Conn 1942 and Allorhizobium undicola de Lajudie et al. 1998 as new combinations: Rhizobium radiobacter, R.rhizogenes, R.rubi, R.undicola and R.vitis. Int J Syst Evol Microbiol 2001; 51(Pt 1): 89-103.

4. Namdari H, Hamzavi S, Peairs RR. Rhizobium (Agrobacterium) radiobacter identified as a cause of chronic endophthalmitis subsequent to cataract extraction. J Clin Microbiol 2003; 41(8): 3998-4000.

5. Paphitou NI, Rolston KV. Catheter-related bacteremia caused by Agrobacterium radiobacter in a cancer patient: case report and literature review. Infection 2003; 31: 421-4.

6. Plotkin GR. Agrobacterium radiobacter prosthetic valve endocarditis. Ann Intern Med 1980; 93(6): 839-40.

7. Owensby JE, Elliott S, Tu K, Hernandez JE. Cellulitis and myositis caused by Agrobacterium radiobacter and Haemophilus parainfluenzae after influenza virus vaccination. South Med J 1997; 90(7): 752-4.

8. Edmond MB, Riddler SA, Baxter CM, Wicklund BM, Pasculle AW. Agrobacterium radiobacter: a recently recognized opportunistic pathogen. Clin Infect Dis 1993; 16(3): 388-91.

9. Miller MJ, Novy C, Hiott M. Case of bacterial endophthalmitis caused by an Agrobacterium radiobacter-like organism. J Clin Microbiol 1996; 34(12): 3212-3.

10. Moreau-Gaudry V, Chiquet C, Boisset S, Croize J, Benito Y, Cornut PL, et al. Three cases of post-cataract surgery endophthalmitis due to Rhizobium (Agrobacterium) radiobacter. J Clin Microbiol 2012 ;50(4): 148790.

11. Pierre-Filho PT, Ribeiro AP, Passos ED, Torigoe M, de Vasconcellos JP. Endophthalmitis caused by Agrobacterium radiobacter. Scand J Infect Dis 2003; 35(6-7): 410-1.

12. Alnor D, Frimodt-Moller N, Espersen F, Frederiksen W. Infections with the unusual human pathogens Agrobacterium species and Ochrobactrum anthropi. Clin Infect Dis 1994; 18(6): 914-20.

13. Butler SL, Doherty Cl, Hughes JE, Nelson JW, Govan JR. Burkholderia cepacia and cystic fibrosis: do natural environments present a potential hazard? J Clin Microbiol 1995; 33(4): 1001-4.

14. Landron C, Le Moal G, Roblot F, Grignon B, Bonnin A, Becq-Giraudon B. Central venous catheter-related infection due to Agrobacterium radiobacter: a report of 2 cases. Scand J Infect Dis 2002; 34(9): 693-4.

15. Detrait M, D'Hondt L, Andre M, Lonchay C, Holemans X, Maton JP, et al. Agrobacterium radiobacter bacteremia in oncologic and geriatric patients: presentation of two cases and review of the literature. Int J Infect Dis 2008; 12(6): e7-10. 
16. Chen CY, Hansen KS, Hansen LK. Rhizobium radiobacter as an opportunistic pathogen in central venous catheter-associated bloodstream infection: case report and review. J Hosp Infect 2008; 68(3): 203-7.

17. Karadeniz A, Aydemir HA, Uyanık MH, Uyanık A, Çankaya E. A rare agent of continuous ambulatory peritoneal dialysis peritonitis: Rhizobium radiobacter. Saudi J Kidney Dis Transpl 2019; 30(1): 250-3.

18. Halas R, Jacob C, Badwal K, Mir R. Rare case of Rhizobium radiobacter bioprosthetic mitral valve endocarditis. IDCases 2017; 10: 88-90.

19. Pinerua-Gonsalvez JF, Zambrano-Infantinot R, Calcano C, Montano C, Fuenmayor Z, Rodney H, et al. Infective endocarditis by Rhizobium radiobacter: a case report. Invest Clin 2013; 54: 68-73.

20. Romano L, Spanu T, Calista F, Zappacosta B, Mignogna S, Sali M, et al. Tsukamurella tyrosinosolvens and Rhizobium radiobacter sepsis presenting with septic pulmonary emboli. Clin Microbiol Infect 2011; 17(7): 1049-52.

21. Wang DL, Zhao LD, Li LJ, Zhou MJ. Septic shock caused by Rhizobium radiobacter in an elderly woman: a case report. Medicine (Baltimore) 2019; 98(49): e18267.

22. Alos JI, de Rafael L, Gonzalez-Palacios R, Aguiar JM, Allona A, Baquero F. Urinary tract infection probably caused by Agrobacterium radiobacter. Eur J Clin Microbiol 1985; 4(6): 596-7.

23. Fenner BJ, Kumar A, Tan NYQ, Ang M. Case of isolated Rhizobium radiobacter contact lens-related infectious keratitis: a plant microbe now emerging as a human pathogen. Am J Ophthalmol Case Rep 2019; 15: 100476.

24. Al-Abdullah AA, Al-Falah M, Al-Rashaed S, Khandekar R, Arevalo JF. Endophthalmitis caused by Rhizobium radiobacter after posterior chamber phakic intraocular lens implantation to correct myopia. J Refract Surg 2015; 31(8): 561-3.

25. Joshi L, Morarji J, Tomkins-Netzer O, Lightman S, Taylor SRJ. Rhizobium radiobacter endophthalmitis following Intravitreal ranibizumab injection. Case Rep Ophthalmol 2012; 3(3): 283-5.

26. Dhatariya K, Gooday C, Morrow D, Murchison R, Turner J, Hutchinson R, et al. Rhizobium radiobacter wound infection in a patient with diabetes-fact, factitious or justplain unlucky? QJM 2012; 105(4): 365-8.

27. Sen V, Sen P, Sahin MO. Fournier gangrene due to Rhizobium radiobacter. Pak J Med Sci 2018; 34(4): $1027-9$.

28. Pereira LA, Chan DS, Ng TM, Lin R, Jureen R, Fisher DA, et al. Pseudo-outbreak of Rhizobium radiobacter infection resulting from laboratory contamination of saline solution. J Clin Microbiol 2009; 47(7): 2256-9.

29. Lai CC, Teng LJ, Hsueh PR, Yuan A, Tsai KC, Tang JL, et al. Clinical and microbiological characteristics of Rhizobium radiobacter infections. Clin Infect Dis 2004; 38(1): 149-53.

30. Amaya RA, Edwards MS. Agrobacterium radiobacter bacteremia in pediatric patients: case report and review. Pediatr Infect Dis J 2003; 22(2): 183-6. 